\title{
IS THE IMMUNOCROMATOGRAPHIC FECAL ANTIGEN TEST EFFECTIVE FOR PRIMARY DIAGNOSIS OF HELICOBACTER PYLORI INFECTION IN DYSPEPTIC PATIENTS?
}

\author{
Magali DALLA NORA 1 , Rosmari HÖRNER ${ }^{2}$, Diego Michelon De CARLI', \\ Marta Pires da ROCHA ${ }^{4}$, Amanda Faria de ARAUJO $^{5}$ and Renato Borges FAGUNDES ${ }^{1,5}$
}

ABSTRACT - Background - The diagnosis of $H$. pylori infection can be performed by non-invasive and invasive methods. The identification through a fecal antigen test is a non-invasive, simple, and relatively inexpensive test. Objective - To determine the diagnostic performance of fecal antigen test in the identification of $H$. pylori infection. Methods - H. pylori antigens were identified in the stools of dyspeptic patients undergoing upper gastrointestinal endoscopy. For the identification of $H$. pylori antigen, we use ImmunoCard STAT! HpSA with immunochromatography technique. Histopathology plus urease test were the gold standard. Results - We studied 163 patients, 51\% male, mean age of $56.7 \pm 8.5$ years. H. pylori infection was present in $49 \%$. Fecal test presented: sensitivity $67.5 \%$ (CI95\% 60.6-72.9); specificity $85.5 \%$ (CI95\% 78.9-90.7); positive predictive value $81.8 \%$ (CI95\% 73.4-88.4) and negative predictive value 73,2\% (CI95\% 67.5-77.6); Positive likelihood ratio was 4.7 (CI95\% 2.9-7.9) and Negative Likelihood Ratio 0.4 (CI95\% 0.3-0.5). The prevalence odds ratio for a positive test was 12.3 (CI95\% 5.7-26.3). The index kappa between FAT and histology/urease test was 0.53 (CI95\% 0.39-0.64). Conclusion - Immunochromatographic FAT is less expensive than the other methods and readily accepted by the patients but its diagnostic performance does not recommend its use in the primary diagnosis, when the patient may have an active infection.

HEADINGS - Helicobacter infections, diagnosis. Immunochromatography. Antibodies. Endoscopy. Digestive system diagnostic techniques.

\section{INTRODUCTION}

Invasive and non-invasive methods can be used for the diagnosis of Helicobacter pylori $(H$. pylori) infection. The invasive methods include histopathology, urease test, and culture. All of them require gastric biopsy through upper GI endoscopy. Non-invasive methods include urea breath test, serologic tests, and fecal antigen test. These tests do not need endoscopy and biopsy. Due to the character invasive of endoscopy and biopsy, there is a growing interest in the use of non-invasive methods ${ }^{(1)}$. Among the non-invasive methods, urea breath test is the most reliable due to its high sensitivity and specificity. However, this test has limitations, such as costly laboratory equipment and the possibility of false-negative results. On the other hand, serologic tests detect markers of exposure to $H$. pylori but do not indicate the existence of active infection, because the antibodies against $H$. pylori may remain present long after its eradication ${ }^{(8)}$.
Fecal antigen test (FAT) identifies antigens of $H$. pylori through monoclonal and polyclonal antibodies in a fecal sample. In 1997 appeared the first FAT with polyclonal antibodies. Currently, most FAT uses monoclonal antibodies. The test can be performed by immuno-enzymatic assay or by immunochromatography assay ${ }^{(8)}$. FAT conducted by immunochromatography is fast and cost effective, because it does not require additional equipment making possible its use in primary care settings ${ }^{(20)}$. Due to these characteristics, the use of FAT by immunochromatography in developing countries is attractive. To the best of our knowledge, only nine studies $^{(2,3,11,13,14,16-18,21)}$ in the past ten years evaluated FAT to diagnosis $H$. pylori infection in Brazil, most of them used immuno-enzymatic assay and only one used immunochromatography ${ }^{(18)}$.

The aim of this study was to identify $H$. pylori infection in dyspeptic patients and determine the diagnostic performance (accuracy, sensitivity, specificity,

Declared conflict of interest of all authors: none

Disclosure of funding: no funding received

'Programa de Pós-Graduação em Ciências da Saúde, Universidade Federal de Santa Maria, RS, Brasil; ${ }^{2}$ Laboratório de Microbiologia, Departamento de Análises Clínicas e Toxicológicas, Faculdade de Farmácia, Universidade Federal de Santa Maria, RS, Brasil; ${ }^{3}$ Serviço de Gastroenterologia do Hospital Universitário, Universidade Federal de Santa Maria, RS, Brasil; ${ }^{4}$ Serviço de Patologia do Hospital Universitário, Universidade Federal de Santa Maria, RS, Brasil; ${ }^{5}$ Departamento de Clínica Médica, Centro de Ciências da Saúde, Universidade Federal de Santa Maria, Santa Maria, RS, Brasil.

Correspondence: Renato Borges Fagundes. Av. Grécia 1000, ap. 1002, Torre B. CEP: 91350-070 - Porto Alegre, RS, Brasil. E-mail: fagundesrb@gmail.com 
positive and negative predictive values and likelihood ratios) of the FAT by immunochromatography using as the gold standard histological examination plus urease test.

\section{METHODS}

Dyspeptic adult patients, undergoing to upper GI endoscopy at the Gastroenterology Unit of University Hospital of Santa Maria, from March 2013-June 2015, were invited to participate in the study. Institutional Internal Review Board approved the protocol study under the number CAAE 11979613.7.0000.5346. We excluded patients treated with antibiotics in the last 30 days or proton pump inhibitors (PPIs) in the last two weeks ${ }^{(2)}$, as well as patients with gastric cancer, gastrectomy, bleeding disorder, acquired immunodeficiency syndrome, congestive heart failure, renal failure, and chronic liver disease.

After upper GI endoscopy examination, we collect six gastric biopsies from each patient. Two biopsies from antrum, one biopsy from incisura angularis and two from the body for histological examination, and one biopsy from the antrum to the urease test. The gastric biopsies were stored in vials containing $10 \%$ formalin and sent to the pathology lab. The histological diagnosis was according to the Sydney system. We followed the manufacturer's guidelines to perform the urease test.

Patients brought fecal samples stored in a box with ice. We froze the samples at $-20^{\circ} \mathrm{C}$ until the completion of the test with the ImmunoCard STAT immuno TAF! Hpsa (Meridian Bioscience, Ohio/USA). This test is based on immunochromatography technique. After homogenization, we collected and transferred 5-6 $\mathrm{mL}$ of sample to a diluent vial. We put four drops of the suspension in the appropriate area on the device test. We incubated the test at room temperature $\left(20-26^{\circ} \mathrm{C}\right)$ for 5 minutes. We executed the reading for 1 minute based upon the appearance of colored lines in the central window. We interpreted as a positive test when it showed a blue control line (C) and a test line $(\mathrm{T})$ in pink-reddish. Appearance only the line $\mathrm{C}$ indicated a negative test. No line $\mathrm{C}$, with or without the line $\mathrm{T}$, pointed out to invalid test. An observer (MDN) unaware of the results of histopathology or urease test read TAF results and classified them as positive, negative or invalid. We used histopathology findings and urease test results, as the gold standard, to assess the accuracy of FAT in the diagnosis of $H$. pylori infection.

\section{Statistical analysis}

We based our sample calculation on a previous study ${ }^{(12)}$, which showed $76 \%$ prevalence of $H$. pylori infection among dyspeptic patients attending the Gastroenterology Unity at Hospital Universitario de Santa Maria. Previous studies demonstrated the sensitivity of the fecal antigen test (ImmunoCard Stat HpSA) to be around 70\%(4). Assuming 70\% of accuracy for fecal antigen test compared to histology and urease test with a difference of $\pm 10 \%(95 \% \mathrm{CI})$, we estimate our sample size in 160 patients.
We used Statistical Package for the Social Sciences v. 17 for data analysis. We organized the data in $2 \times 2$ contingency tables for calculation of sensitivity, specificity, positive and negative predictive values, and the likelihood ratios (positive and negative) of FAT in the identification of $H$. pylori infection. We used Fisher exact test to appraise the statistical significance and Cohen's kappa coefficient to assess the agreement between FAT and the combination of histopathology examination and urease test at the significance level of $\alpha<0.05$.

\section{RESULTS}

We included 165 patients with a mean age of $56.7(\mathrm{SD} \pm 8.5)$ years. Fifty-one percent were male. Eighty patients $(49 \%)$ presented $H$. pylori infection assessed by histopathology/urease test (Table 1). We excluded two patients with FAT results classified as invalid. The contingency table $2 \times 2$ (Table 2 ) shows FAT results compared to histopathology/urease test, for 163 patients.

FAT performance for the diagnosis of $H$. pylori infection is detailed in Table 3. Cohen's kappa index for the agreement between FAT and histopathology/urease test was 0.53 (95\% CI: 0.39-0.64).

TABLE 1. Sample demographics plus urease test and histopathology results

\begin{tabular}{lccc}
\hline Variable & Category & $\mathbf{N}$ & $\%$ \\
\hline \multirow{2}{*}{ Age (years) } & $20-40$ & 42 & 25.7 \\
& $41-60$ & 89 & 54.6 \\
Genre & $61-80$ & 32 & 19.6 \\
& Female & 80 & 49.1 \\
Urease test* & Male & 83 & 50,9 \\
& Positive & 75 & 46.1 \\
Histopathology* & Negative & 88 & 53.9 \\
& Positive & 80 & 49.0 \\
* Cohen's kappa index $=0.94($ CI95\% & Negative & 83 & 51.0
\end{tabular}

TABLE 2. Comparison between FAT and histopathology/urease test for diagnosis of $H$. pylori infection

\begin{tabular}{ccccc}
\hline & \multicolumn{3}{c}{ Histophatology/ Urease test } \\
\cline { 3 - 5 } & & Positive & Negative & Total \\
\hline \multirow{2}{*}{ FAT } & Positive & 54 & 12 & 66 \\
& Negative & 26 & 71 & 97 \\
& Total & 80 & 83 & 163 \\
\hline
\end{tabular}

$P<0.001$

TABLE 3. FAT performance for the diagnosis of $H$. pylori infection

\begin{tabular}{lcc}
\hline & $\%$ & $95 \%$ CI \\
\hline Acuracy & 76.7 & $70-82$ \\
Sensitivity & 67.5 & $60.6-72.9$ \\
Specificity & 85.5 & $78.9-90.7$ \\
Positive predictive value & 81.8 & $73.4-88.4$ \\
Negative predictive value & 73.2 & $67.5-77.6$ \\
Positive likelihood ratio & 4.7 & $2.9-7.9$ \\
Negative likelihood ratio & 0.4 & $0.3-0.5$ \\
\hline
\end{tabular}




\section{DISCUSSION}

In this study, we found that FAT with immunochromatography technique in the diagnosis of $H$. pylori infection presented a moderate agreement with histopathology and urease test. FAT showed high specificity, low sensitivity, high predictive positive value (PPV) and moderate negative predictive value (NPV). Its high specificity pointed out to a low rate of false-positive values, and the low sensitivity raised the probability of high rate of false-negative results. The positive likelihood ratio suggested a small increase in the probability of active $H$. pylori infection in a patient when compared with one who tested negative.

The high specificity of FAT indicates that the exam can provide a significant percentage of correct results when individuals do not have $H$. pylori infection. This high specificity determines the probability that the test does not select erroneously uninfected people. On the other hand, the low sensitivity demonstrates the inability of the test in making the diagnosis when the patient has $H$. pylori infection. The predictive values of a test are not exclusive properties of the test because their values depend on the prevalence of the disease among the population. The high PPV indicates that a patient with a positive test has a high probability of presenting the infection. The moderate NPV means that the exam has an average chance to predict the non-existence of the infection when it does not exist.

The results of this imunocromatographic test are in disagreement with the immunoassay tests executed in Brazil ${ }^{(2,3,11,13,14,16-18,21)}$. Our results are also in disagreement with some results obtained even in different areas of the world, by immunocromatographic assay ${ }^{(4,9,18)}$. On the other hand, our results are similar to results achieved in Egypt ${ }^{(1,5)}$. Egypt has a high prevalence of $H$. pylori infection. It is noteworthy that the performance of immunochromatographic tests depends on the patient's characteristics. The sensitivity and specificity are higher in patients with ulcer. Otherwise, the sensitivity decreases in patients who are more than 60 years ${ }^{(4)}$. The age could be an explanation for the lower sensitivity achieved in our results, once the mean age of our sample was around 60 years/old. Due to its high specificity and high PPV the test could be useful in younger patients making them candidates for the test and treat approach.

Many others factors exert influence in the FATs results. Watery fecal samples reduce FATs accuracy because of the H. pylori antigens dilution, but none of the patients included in this study presented watery samples. Other factors are PPIs. Antibiotics and bismuth salts use. To avoid bias we did not included patients in use of these drugs. Therefore, the cause of false negative results is not related to the temporary inhibition of $H$. pylori. However, false negative results could be due to a low colonization in the gastric mucosa. Decreased colonization of gastric mucosa might lead to low concentration of $H$. pylori antigens in stool, not enough to react in FAT. False-positive results may also have occurred due to the presence of a coccoid form of $H$. pylori. This form despite to be a morphological manifestation of bacterial death, induces antigen detected by the test ${ }^{(21)}$.

Our results are in agreement with other studies ${ }^{(7,8,15,19)}$. It is reported an irregular performance of FAT in comparison to other methods, a wide variation of accuracy and antigenicity differences among strains of $H$. pylori in distinct populations ${ }^{(9,10,20)}$. Thus, the tests' sensitivity must be investigated in each population prior its use in practice. It is also possible to occur misinterpretation of FAT results with immunochromatography technique. A weaker band in the test, as well as problems of affinity in antigen-antibody binding and insufficient analytical sensitivity are responsible for the diagnostic misinterpretation ${ }^{(22)}$. Some authors observed considerable differences in FAT evaluations of dyspeptic patients and suggested that FAT with immunochromatography technique presents unpredictable results as a tool for the primary diagnosis and good results for the assessment of $H$. pylori eradication ${ }^{(6,20)}$.

The considerable genetic heterogeneity and the wide geographic variation in $H$. pylori strains may be compromised our results. The differences between antigens and antibodies may have influenced the results ${ }^{(9,20)}$. The older age of our sample and the predominance of women could be another possible bias. Intestinal constipation is more frequent among older people and female, and slow movement of intestines can determine a greater chance of $H$. pylori antigen degradation ${ }^{(5)}$.

\section{CONCLUSION}

Although immunochromatographic FAT is less expensive than the other methods and readily accepted by the patients its diagnostic performance does not recommend its use in the primary diagnosis, when the patient may have an active infection.

\section{Authors' contributions}

Fagundes RB e Dalla Nora $M$ designed the research protocol. Dalla Nora M conducted the process for IRB permission and coordinated the samples collection. Dalla Nora $\mathrm{M}$ and Hörner R performed the immunochromatography technique for fecal antigen test. De Carli DM and Araujo AF collected biopsies and performed the urease tests. Rocha MP performed the anatomopathological diagnosis. Fagundes RB analyzed the data and wrote the manuscript. All authors read and approved the manuscript final version for submission. 
Dalla Nora M, Hörner R, De Carli DM, Rocha MP, Araujo AF, Fagundes RB. Teste imunocromatográfico do antígeno fecal: efetivo no diagnóstico primário da infecção por Helicobacter pylori em pacientes dispépticos? Arq Gastroenterol. 2016,53(4):224-7.

RESUMO - Contexto - O diagnóstico da infecção por Helicobacter pylori (H. pylori) pode ser realizado por métodos invasivos e não invasivos. A identificação através do teste do antígeno fecal é um método não invasivo, simples, fácil e relativamente barato. Objetivo - Determinar o desempenho diagnóstico do teste fecal imunocromatográfico na identificação da infecção pelo H. pylori. Métodos - A pesquisa de antígenos fecais do H. pylori foi realizada através do ImmunoCard STAT! HpSA em pacientes dispépticos submetidos à endoscopia digestiva alta com coleta de biópsias para histopatologia e teste da urease, utilizados como padrão ouro. Resultados - Foram estudados 163 pacientes, $51 \%$ do sexo masculino, com idade média de 56,7 \pm 8,5 anos. A infecção por $H$. pylori esteve presente em 49\%. O teste fecal apresentou o seguinte desempenho diagnóstico: sensibilidade 67,5\% (IC95\% 60,6-72,9), especificidade 85,5\% (IC95\% 78,9-90,7), valor preditivo positivo 81,8\% (IC95\% 73,4-88,4) e valor preditivo negativo 73,2\% (IC95\% 67,5-77,6). A razão de probabilidade positiva foi 4,7 (IC95\% 2,9-7,9) e a razão de probabilidade negativa foi 0,4 (IC95\% 0,3-0,5). A razão de chances de prevalência para teste fecal positivo foi 12,3 (IC95\% 5,7-26,3). O índice kappa para a concordância do teste fecal com histologia/teste da urease foi 0,53 (IC95\% 0,39-0,64) Conclusãa - O teste fecal imunocromatográfico apresenta baixo custo e é facilmente aceito pelos pacientes, no entanto seu desempenho diagnóstico não o recomenda para diagnóstico primário.

DESCRITORES - Infecções por Helicobacter, diagnóstico. Imunocromatografia. Anticorpos. Endoscopia. Técnicas de diagnóstico do sistema digestório.

\section{REFERENCES}

1. Alam El-Din HM, Hashem AG, Ragab YM, Hussein IL, Mohamed DB, Mohamed E-CB. Evaluation of noninvasive versus invasive techniques for the diagnosis of Helicobacter pylori infection. Appl Immunohistochem Mol Morphol. 2013;21:326-33.

2. Chehter EZ, Bacci MR, Fonseca FL, Gonçalves JA, Buchalla G, Shiraichi SA, et al. Diagnosis of the infection by the Helicobacter pylori through stool examination: method standardization in adults. Clin Biochem. 2013;46:1622-4.

3. de Carvalho Costa Cardinali L, Rocha GA, Rocha AM, de Moura SB, de Figueiredo Soares T, Esteves AM, et al. Evaluation of [13C]urea breath test and Helicobacter pylori stool antigen test for diagnosis of $H$. pylori infection in children from a developing country. J Clin Microbiol. 2003;41:3334-5.

4. Jekarl DW, An YJ, Lee S, Lee J, Kim Y, Park YJ, et al. Evaluation of a newly developed rapid stool antigen test using an immunochromatographic assay to detect Helicobacter pylori. Jpn J Infect Dis. 2013;66:60-4.

5. Kamel HY, Abd-Al-Atty MF, El-Banoby MH, El-Baz AA, Sakr MA, Ahmed NS, et al. Stool antigen test in diagnosis of Helicobacter pylori in older adults with dyspepsia. [letter]. J Am Geriatr Soc. 2011;59:1769-70.

6. Kodama M, Murakami K, Okimoto T, Fukuda Y, Shimoyama T, Okuda M, et al. Influence of proton pump inhibitor treatment on Helicobacter pylori stool antigen test. World J Gastroenterol. 2012;18:44-8.

7. Korkmaz H, Findik D, Ugurluoglu C, Terzi Y. Reliability of stool antigen tests: investigation of the diagnostic value of a new immunochromatographic Helicobacter pylori approach in dyspeptic patients. Asian Pac J Cancer Prev. 2015;16:657-60.

8. Korkmaz H, Kesli R, Karabagli P, Terzi Y. Comparison of the diagnostic accuracy of five different stool antigen tests for the diagnosis of Helicobacter pylori infection. Helicobacter. 2013;18:384-91.

9. Lario S, Ramírez-Lázaro MJ, Montserrat A, Quílez ME, Junquera F, Martínez-Bauer E, et al. Diagnostic accuracy of three monoclonal stool tests in a large series of untreated Helicobacter pylori infected patients. Clin Biochem. 2016

10. Lee YC, Tseng PH, Liou JM, Chen MJ, Chen CC, Tu CH, et al. Performance of a one-step fecal sample-based test for diagnosis of Helicobacter pylori infection in primary care and mass screening settings. J Formos Med Assoc. 2014;113:899-907.
11. Miranda AC, Machado RS, Kawakami E. Spontaneous elimination of Helicobacter pylori infection in a cohort of asymptomatic school children by enzyme-linked immunosorbent assay polyclonal antigen in stool. J Clin Gastroenterol. 2008;42:143-6.

12. Muller LB, Fagundes RB, Moraes CC, Rampazzo A. [Prevalence of Helicobacter pylori infection and gastric cancer precursor lesions in patients with dyspepsia]. Arq Gastroenterol. 2007;44:93-8.

13. Parente JM, da Silva BB, Palha-Dias MP, Zaterka S, Nishimura NF, Zeitune JM. Helicobacter pylori infection in children of low and high socioeconomic status in northeastern Brazil. Am J Trop Med Hyg. 2006;75:509-12.

14. Queiroz DM, Saito M, Rocha GA, Rocha AM, Melo FF, Checkley W, et al. Helicobacter pylori infection in infants and toddlers in South America: concordance between [13C] urea breath test and monoclonal H. pylori stool antigen test. J Clin Microbiol. 2013;51:3735-40.

15. Rafeey M, Nikvash S. Detection of Helicobacter pylori antigen in stool samples for diagnosis of infection in children. East Mediterr Health J. 2007;13:1067-72.

16. Raguza D, Granato CF, Kawakami E. Evaluation of the stool antigen test for Helicobacter pylori in children and adolescents. Dig Dis Sci. 2005;50:453-7.

17. Raguza D, Machado RS, Ogata SK, Granato CF, Patrício FR, Kawakami E. Validation of a monoclonal stool antigen test for diagnosing Helicobacter pylori infection in young children. J Pediatr Gastroenterol Nutr. 2010;50:400-3.

18. Sanches BSF MGM, Pinto HAF, Meira ACD, Alves EJ, Trindade OR, Cota BDCV, Coelho LGV. Evaluation of stool antigen test on initial diagnosis and control test of Helicobacter pylory eradication. Helicobacter. 2013;18:122.

19. Segamwenge IL, Kagimu M, Ocama P, Opio K. The utility of the Helicobacter pylori stool antigen test in managing dyspepsia: an experience from a low resource setting. Afr Health Sci. 2014;14:829-34.

20. Shimoyama T. Stool antigen tests for the management of Helicobacter pylori infection. World J Gastroenterol. 2013;19:8188-91.

21. Silva JM, Villares CA, Monteiro MS, Colaúto C, dos Santos AF, Mattar R. Validation of a rapid stool antigen test for diagnosis of Helicobacter pylori infection. Rev Inst Med Trop Sao Paulo. 2010;52:125-8.

22. Zhou X, Su J, Xu G, Zhang G. Accuracy of stool antigen test for the diagnosis of Helicobacter pylori infection in children: a meta-analysis. Clin Res Hepatol Gastroenterol. 2014;38:629-38 